No $2011-28$

December

CENTRE

D'ÉTUDES PROSPECTIVES

ET D'INFORMATIONS

INTERNATIONALES

Index Trading and Agricultural Commodity Prices:

A Panel Granger Causality Analysis

Gunther Capelle-Blancard and Dramane Coulibaly 


\section{TABLE OF CONTENTS}

Non-technical summary. . . . . . . . . . . . . . . . . . . . . . . . . . . 3

Abstract . . . . . . . . . . . . . . . . . . . . . . . . . . . . . 3

Résumé non technique . . . . . . . . . . . . . . . . . . . . . . . . . . . 4

Résumé court . . . . . . . . . . . . . . . . . . . . . . . . . . . 5

1. Introduction . . . . . . . . . . . . . . . . . . . . . . . . . . . . . . 6

2. Econometric methodology . . . . . . . . . . . . . . . . . . . . 8

3. Data . . . . . . . . . . . . . . . . . . . . . . . . 11

4. Empirical results . . . . . . . . . . . . . . . . . . . . . . . . . . 16

5. Conclusion . . . . . . . . . . . . . . . . . . . . . . . . . . . . . . 21

List of working papers released by CEPII . . . . . . . . . . . . . . . . . . . . 25 


\title{
Index Trading and Agricultural Commodity Prices: A Panel Granger Causality analysis
}

\section{NON-TECHNICAL SUMMARY}

Since the 2008 global food crisis, and with the new price surge in 2010-2011, agricultural commodity markets have been at the heart of the world economic concerns. It is likely that several fundamental factors (crop failures, extreme weather events, biofuel development, emerging economies growth, monetary instability...) have played a role, but there are also reasons to suspect that financial markets could have been partly responsible for the price increase. Indeed, at the same time prices of commodities rose substantially, financial investments in agricultural commodities soared. This increase was mainly driven by index-based investments, that led to the "financialization" of agricultural commodity markets.

Several studies have examined the causality between commodity prices and positions on futures markets. Overall, they generate no evidence that index trading had an impact on price changes (see Irwin and Sanders (2011) for a survey). However, as stated by Sanders and Irwin (2011b), the power of the standard statistical tests might be too low. Accordingly, they suggest to consider SUR estimations to take crosssectional dependence across markets into account. In this paper, we aim to contribute to the literature by using the panel Granger causality testing approach recently developed by Kònya (2006). More precisely, we consider SUR estimation and bootstrap specific critical values. This approach does not suppose homogeneity in the panel and does not require preliminary tests for unit roots and cointegration.

Our causality tests are applied to the relationship between index-based positions and futures prices on weekly data for twelve grain, livestock and other soft commodity markets (cocoa, coffee, corn, cotton, feeder cattle, live cattle, lean hogs, soybeans, soybean oil, sugar, wheat-CBOT and wheat-KCBT) over the period 2006-2010. Our results confirm the absence of direct effect between index-based trading and commodity prices.

\begin{abstract}
This paper investigates the causality between prices and index-based trading activity for twelve grain, livestock, and other soft commodity futures markets. We use panel Granger causality estimations based on SUR systems and Wald tests with market-specific bootstrap critical values. This approach allows to test for causality on each market by accounting for the possible contemporaneous dependence across markets. Our results confirm that there is no causality between index-based positions and commodity futures prices.
\end{abstract}

JEL Classification: G10, Q10.

Keywords: $\quad$ Speculation, financialization, food crisis, soft commodities, index funds, panel Granger causality. 


\section{FONDS INDICIELS ET PRIX DES PRODUITS AGRICOLES UNE ANALYSE de CAUSALITÉ EN PANEL}

\section{RÉSUME NON TECHNIQUE}

Depuis la crise alimentaire de 2008, et avec la nouvelle flambée des prix en 2010-2011, les marchés agricoles sont au cœur des préoccupations économiques mondiales, au point de figurer au premier rang des priorités du G20. De nombreux facteurs sont régulièrement cités pour expliquer la hausse des prix sur les marchés agricoles : les mauvaises récoltes, la recrudescence des événements climatiques extrêmes, le développement des biocarburants, le décollage des économies émergentes, l'instabilité monétaire... sans oublier le rôle potentiellement déstabilisant des marchés financiers.

Ces dernières années, on observe sur les marchés de matières premières (agricoles, énergétiques et minérales), une montée en puissance, aux côtés des spéculateurs, d'une nouvelle catégorie d'acteurs : les fonds indiciels. Les spéculateurs traditionnels cherchent à profiter des tendances haussières ou baissières sur le marché : ils prennent pour cela des positions à court terme et sont alternativement acheteurs et vendeurs. Les fonds indiciels voient davantage dans les matières premières une source de diversification; ils prennent essentiellement des positions longues sur les marchés à terme qu'ils renouvellent régulièrement. Cet essor des fonds indiciels s'est traduit par une financiarisation des matières premières. Quels sont les conséquences de cette financiarisation?

Les inquiétudes concernant les marchés financiers et leur impact déstabilisateur sont au moins aussi anciennes que la création des marchés eux-mêmes et les économistes se sont très tôt emparés de cette question. D’Adam Smith (1776) à Milton Friedman (1953), en passant par John Stuart Mill (1871), la position traditionnelle est de considérer que les spéculateurs ont un rôle stabilisant. Cette approche repose toutefois sur une vision idéalisée des marchés financiers. Depuis Baumol (1957), de nombreux économistes ont formellement montré que la spéculation pouvait être déstabilisante en présence d'imperfections de marché (autrement dit, dès lors qu'il y a des obstacles aux opérations d'arbitrage, des asymétries d'information, des possibilité de manipulation des cours, etc.). La question du rôle (dé)stabilisateur de la spéculation et des marchés à terme a également suscité de très nombreuses études empiriques, les premières datant de la fin du XIXème siècle. Malgré l'abondance des travaux, les résultats sont en général guère conclusifs. Si l'on s'en tient aux études qui portent sur les marchés de matières premières, alors il apparaît que les marchés financiers n'ont pas d'influence directe sur les prix, y compris au cours de la dernière décennie (voir Irwin et Sanders (2011) pour une synthèse).

Dans cette étude nous proposons de ré-examiner cette question en utilisant les techniques d'estimation économétriques les plus récentes. Plus précisément, nous utilisons la méthodologie des tests de causalité au sens de Granger en panel. Notre approche repose sur l'estimation d'un modèle SUR (Seemingly Unrelated Regression) et sur le calcul de valeurs critiques à partir de la technique du bootstrap. Cette approche permet de renforcer la puissance des tests de causalité standard, en tenant compte de la dépendance statistique contemporaine qui existe entre les différents marchés (Kònya (2006)). Nos tests sont appliqués à douze produits agricoles (maïs, soja, huile de soja, deux catégories de blé, sucre, cacao, coton, deux 
catégories de bovins, porc maigre, café) traités sur les marchés à terme américains sur la période 20062010. Les données utilisées sont celles fournies par l'autorité américaine en charge des marchés à terme, la CFTC. Nos résultats confirment qu'il n'y a pas de lien de causalité direct entre les positions des fonds indiciels et les prix sur les marchés agricoles.

\section{RÉSUMÉ COURT}

Depuis la crise alimentaire de 2008, et avec la nouvelle flambée des prix en 2010-2011, les marchés de matières premières (agricoles, énergétiques et minérales) sont au cœur des préoccupations économiques mondiales. Dans ce contexte, les craintes sont vives concernant le rôle potentiellement déstabilisant des marchés financiers. D'autant qu'on a assisté, ces dernières années, à une financiarisation des marchés de commodités, alimentée par la montée en puissance des fonds indiciels qui voient dans ces marchés une nouvelle source de diversification. Nous étudions les relations qui peuvent exister entre les positions des investisseurs sur les marchés de commodités et les prix. Plus précisément, nous utilisons la méthodologie des tests de causalité au sens de Granger en panel. Notre approche repose sur l'estimation d'un modèle SUR (Seemingly Unrelated Regression) et sur le calcul de valeurs critiques à partir de la technique du bootstrap. Cette approche permet de renforcer la puissance des tests de causalité standard en tenant compte de la dépendance statistique contemporaine qui existe entre les marchés. Nos tests sont appliqués à douze produits agricoles (maïs, soja, huile de soja, deux catégories de blé, sucre, cacao, coton, deux catégories de bovins, porc maigre et café) traités sur les marchés à terme américains sur la période 20062010. Nos résultats confirment l'absence de lien de causalité direct entre les positions des fonds indiciels et les prix sur les marchés agricoles.

Classification JEL : G10, Q10.

Mots clés : $\quad$ Spéculation, financiarisation, crise alimentaire, fonds indiciels, causalité à la Granger en panel. 


\title{
Index Trading and Agricultural Commodity Prices: A Panel Granger Causality Analysis ${ }^{1}$
}

\author{
Gunther Capelle-Blancard* \\ Dramane Coulibaly ${ }^{\dagger}$
}

\section{INTRODUCTION}

Since the 2008 global food crisis, and with the new price surge in 2010-2011, agricultural commodity markets have been at the heart of the world economic concerns and have become, for the first time in 2011, a top priority for the G20. Many factors are regularly mentioned to explain the recent episodes of price increase of commodities: crop failures, extreme weather events, biofuel development, emerging economies growth, monetary instability. ${ }^{2}$ It is likely that all these fundamental factors have played a role, but there are also reasons to suspect that financial markets could have been partly responsible for the surge in commodity prices. Indeed, at the same time prices of commodities rose substantially, there was an important increase in financial investments in commodities, particularly in agricultural commodities. This increase was driven by index-based investments, which now account for a great part of total positions in the commodity derivatives markets. According to Irwin and Sanders (2011), at least $\$ 100$ billion of new investment moved into commodity futures markets over the period 2004-2008. The increasing importance of financial investment in commodities - which refers to the concept of "financialization" of commodities (Domanski and Heath (2007), Singleton (2011), Tang and Xiong (2011)) - has been viewed as a source of the price increase.

Admittedly, every time there is pressure on commodity prices, speculators and derivatives markets are blamed. But what is fairly new today is that some practitioners share this view too. For instance, Jim O'Neill, chief economist at Goldman Sachs, highlights the role of the BRICs, but clearly acknowledges that agricultural markets are victims of a speculative bubble: "I see so much focus on food, and it seems to be so trendy in the investment world (...). The underlying dilemma has been created by the wealth of the BRICs (Brazil, Russia, India, China) countries; but, for the past year or so, it's also been a major theme for financial institutions. The markets seem to me to have a bubble-like quality" (The Guardian - April 20, 2008). George Soros him-

\footnotetext{
${ }^{1}$ The authors thank Agnès Bénassy-Quéré, Valérie Mignon and Sophie Piton for helpful comments. The usual disclaimer applies.

*CES, Université Paris 1 Panthéon-Sorbonne \& CEPII. Email: gunther.capelle-blancard@univ-paris1.fr. Corresponding author: 106-112 Bd de l'hopital 75647 Paris Cedex 13 France. Phone:+33 (0)1 44078270.

†CEPII. Email: dramane.coulibaly@ cepii.fr

${ }^{2}$ See Frankel and Rose (2010) for a comprehensive model of the determinants of commodity prices.
} 
self is even more affirmative: "You have a generalized commodity bubble due to commodities having become an asset class that institutions use to an increasing extent" (April 16, 2008).

In fact, the most circumspect seems to be the academics. Concerns about the potential destabilizing impact of speculation are as old as the creation of financial markets themselves, and economists have tackled this issue early. From Adam Smith (1776) to Milton Friedman (1953), through John Stuart Mill (1871), the traditional approach is to consider that speculators have a stabilizing role. However, this approach relies on an idealized vision of financial markets where there are no limits to arbitrage, no information asymmetries, no possibility of manipulation, etc. Baumol (1957) was the first to consider, in a formal setting, that speculation could be destabilizing in the presence of market imperfections. This idea has been developed, in particular, by Hart and Kreps (1986) and the literature on behavioral finance - see DeLong et al. (1990) among others. More specifically, several theoretical models have examined the effects associated with the introduction of derivatives markets. A first category of models aims to clarify the link between futures markets, production and storage. Peck (1976), Turnovsky (1983) and Kawai (1983) conclude that futures markets have a rather stabilizing impact, while for Chari et al. (1990) the effect is ambiguous. A second approach focuses on the information conveyed by futures markets and the difficulty of interpreting this information. Danthine (1978) and Stein (1987) show that futures contracts can be destabilizing if speculators have imperfect information, because then other agents over-react to what they think is private information. For Guesnerie and Rochet (1993), even if futures markets lower price volatility at equilibrium, learning effects related to the difficulty to anticipate the behavior of the others make the equilibrium difficult or impossible to achieve. Bowman and Faust (1997) also give two examples where the introduction of options leads to sunspot equilibrium. ${ }^{3}$

The question of the (de)stabilizing impact of derivatives markets has also attracted a large number of empirical studies. The traditional approach is to compare the volatility on the underlying market before and after the introduction of derivatives. Obviously, this approach suffers from a serious drawback since the introduction of derivatives is very unlikely exogenous. Moreover, one can also argue that volatility does not reflect extreme risks. Anyhow, several studies have examined the effects of the introduction of commodity futures on spot market stability. The first empirical studies date back to the late nineteenth century (Emery, 1898; Hooker, 1901) and they concluded that derivatives have a rather stabilizing impact. More recently, Tomek (1971) (wheat), Taylor and Leuthold (1974) (cattle), Weaver and Banerjee (1990) (cattle), Netz (1995) (wheat) and Fleming and Ostdiek (1999) (crude oil) also find a decrease in volatility or do not detect any particular effect. Only Brorsen (1989) (cattle) suggests that volatility could be higher. ${ }^{4}$

Another approach is to examine whether trades on futures markets cause price movements of the

\footnotetext{
${ }^{3}$ See Mayhew (2002) or Capelle-Blancard (2010) for a survey.

${ }^{4}$ The finding that volatility tends to decline after the introduction of derivatives is not specific to commodity markets, but stands also for fixed income futures, stock index futures, or individual equity options. See Mayhew (2002).
} 
underlying assets. Over the past two years, several studies have analyzed the causality between changes in commodity prices and positions of various types of traders on derivatives markets. ${ }^{5}$ The list includes IMF (2008), Büyüksahin and Harris (2009), Brunetti and Büyüksahin (2009), Gilbert (2010a,b), Stoll and Whaley (2010), and Sanders and Irwin (2010, 2011a,b) - see Irwin and Sanders (2011) for a survey. Most studies on the financialization of commodity markets use data provided by the US Commodity Futures Trading Commission (CFTC). Overall, these studies generate no evidence that index trading in commodities had an impact on price changes. However, as stated by Sanders and Irwin (2011b), the power of the standard statistical tests might be too low. Accordingly, they suggest to consider SUR estimation in order to take crosssectional dependence across markets into account. In this paper, we aim to contribute to the existing literature by using the panel Granger causality testing approach recently developed by Kònya (2006). More precisely, we consider SUR estimation and bootstrap specific critical values to examine the causality between futures prices and index traders positions. This approach does not suppose homogeneity in the panel, as in Sanders and Irwin (2011b). Further, contrary to Sanders and Irwin (2011b), our approach does not require the preliminary tests for unit roots and cointegration which generally suffer from low power as well. We also examine whether the causal link between futures prices and index traders positions is the same before the crisis (January 2006 to September 2008) and during the crisis (September 2008 to December 2010).

Our causality tests are applied on the relationship between traders positions and commodity futures prices on weekly data for twelve grain, livestock, and other soft futures markets over the period 2006-2010. Our results confirm the absence of direct effect between index-based trading and commodity futures prices.

The remainder of the paper is organized as follows. Section 2 presents the methodology. Section 3 describes the data. Section 4 reports the empirical results. Finally, Section 5 offers some concluding remarks.

\section{ECONOMETRIC METHODOLOGY}

Three approaches can be implemented to test for Granger-causality in a panel framework. The first one is based on the Generalized Method of Moments (GMM) that estimates (homogeneous) panel models by eliminating the fixed effects. However, it does not account for either heterogeneity or the cross-sectional dependence. ${ }^{6}$ A second approach that deals with heterogeneity was proposed by Hurlin (2008), but it does not enable for the possible cross-sectional

\footnotetext{
${ }^{5}$ Several papers also examined the lead-lag relationships between spot prices and and futures prices. The purpose of these studies is somehow different in that they look at the price discovery process. Theoretically, futures markets should dominate spot markets, because transaction costs are lower. Most of the studies support this view and show that price changes on derivatives markets lead price changes on spot markets. See Hernandez and Torero (2100) for recent evidence (they examine linear and nonlinear causality between spot and futures returns for corn, two varieties of wheat and soybeans from 1994 to 2009).

${ }^{6}$ Moreover, as shown by Pesaran et al. (1999) the GMM estimators can lead to inconsistent and misleading estimated parameters unless the slope coefficients are in fact identical.
} 
dependence. The third approach developed by Kònya (2006) allows to account for both the cross-sectional dependence and the heterogeneity. It is based on Seemingly Unrelated Regressions (SUR) systems and Wald tests with market specific bootstrap critical values and enables to test for Granger-causality on each individual panel member separately, by taking into account the possible contemporaneous correlation across countries. Given its generality, we will implement this last approach in this paper. ${ }^{7}$

The relationship between futures prices (in $\log$ ), denoted by $P$, and index traders net long positions (number of contracts in million), denoted by $I$, can be studied using the following bivariate finite-order vector autoregressive (VAR) model:

$$
\left\{\begin{array}{c}
P_{i, t}=\alpha_{1, i}+\sum_{s=1}^{l p_{i}} \beta_{1, i, s} P_{i, t-s}+\sum_{s=1}^{l i_{i}} \gamma_{1, i, s} I_{i, t-s}+\varepsilon_{1, i, t} \\
I_{i, t}=\alpha_{2, i}+\sum_{s=1}^{l p_{i}} \beta_{2, i, s} P_{i, t-s}+\sum_{s=1}^{l i_{i}} \gamma_{2, i, s} I_{i, t-s}+\varepsilon_{2, i, t}
\end{array}\right.
$$

where $i=1, \ldots, N$ denotes an agricultural futures market, $t=1, \ldots, T$ the period (week), $s$ the lag, and $l p_{i}$ and $l i_{i}$ the lag lengths. The error terms, $\varepsilon_{1, i, t}$ and $\varepsilon_{2, i, t}$ are supposed to be white noises (i.e. they have zero mean, constant variances and are individually serially uncorrelated) and may be correlated with each other for a given market.

There is one-way Granger-causality running from $I$ to $P$ if in the first equation not all $\gamma_{1, i}$ 's are zero but in the second all $\beta_{2, i}$ 's are zero; there is one-way Granger-causality from $P$ to $I$ if in the first equation all $\gamma_{1, i}$ 's are zero but in the second not all $\beta_{2, i}$ 's are zero; there is two-way Granger-causality between $P$ and $I$ if neither all $\beta_{2, i}$ 's nor all $\gamma_{1, i}$ 's are zero; and there is no Granger-causality between $P$ and $I$ if all $\beta_{2, i}$ 's and $\gamma_{1, i}$ 's are zero.

We can rewrite system (1) by the following two sets of equations:

$$
\left\{\begin{array}{l}
P_{1, t}=\alpha_{1,1}+\sum_{s=1}^{l p_{1}} \beta_{1,1, s} P_{1, t-s}+\sum_{s=1}^{l i_{1}} \gamma_{1,1, s} I_{1, t-s}+\varepsilon_{1,1, t} \\
P_{2, t}=\alpha_{1,2}+\sum_{s=1}^{l p_{1}} \beta_{1,2, s} P_{2, t-s}+\sum_{s=1}^{l i_{1}} \gamma_{1,2, s} I_{2, t-s}+\varepsilon_{1,2, t} \\
\vdots \\
P_{N, t}=\alpha_{1, N}+\sum_{s=1}^{l p_{1}} \beta_{1, N, s} P_{N, t-s}+\sum_{s=1}^{l i_{1}} \gamma_{1, N, s} I_{N, t-s}+\varepsilon_{1, N, t}
\end{array}\right.
$$

\footnotetext{
${ }^{7}$ Arouri and Rault (2010) use a similar method to investigate the relationship between oil prices and stock markets in Gulf Corporation Council countries.
} 
and

$$
\left\{\begin{array}{l}
I_{1, t}=\alpha_{2,1}+\sum_{s=1}^{l p_{2}} \beta_{2,1, s} P_{1, t-s}+\sum_{s=1}^{l i_{2}} \gamma_{2,1, s} I_{1, t-s}+\varepsilon_{2,1, t} \\
I_{2, t}=\alpha_{2,2}+\sum_{s=1}^{l p_{2}} \beta_{2,2, s} P_{2, t-s}+\sum_{s=1}^{l i_{2}} \gamma_{2,2, s} I_{2, t-s}+\varepsilon_{2,2, t} \\
\vdots \\
I_{N, t}=\alpha_{2, N}+\sum_{s=1}^{l p_{2}} \beta_{2, N, s} P_{N, t-s}+\sum_{s=1}^{l i_{2}} \gamma_{2, N, s} I_{N, t-s}+\varepsilon_{2, N, t}
\end{array}\right.
$$

Compared to (1), each equation in (2), and also in (3), has different predetermined variables. The only possible link among individual regressions is contemporaneous correlation within the systems. Therefore, systems 2 and 3 must be estimated by SUR procedure to take contemporaneous correlations into account within the systems (in presence of contemporaneous correlation the SUR estimator is more efficient than the OLS estimator). Following Kònya (2006), we implement Granger causality tests using market specific bootstrap Wald critical values that are generated by 10,000 replications. $^{8}$ For each market the bootstrap critical values depend on the stationarity properties of the corresponding series and the cross-dependence with the other markets. A high number of replications avoids to obtain misleading results.

There are many advantages from this panel causality approach. First, it does not suppose homogeneity in the panel, so it enables to test for Granger-causality on each individual market separately by taking into account the possible contemporaneous dependence across markets. Second, since bootstrap critical values are generated, this approach does not require preliminary tests for unit roots and cointegration (it only requires specification of the lag structure). ${ }^{9}$ This is a good property since the unit root and cointegration tests generally suffer from low power, and different tests often give contradictory findings. Finally, this panel Granger causality approach enables to find for which markets of the panel there exists one-way Granger-causality, two-way Granger-causality or no Granger-causality.

Since the concern is about the influence of speculation on prices, as in the previous studies, we consider only the results of causality from $I$ (index traders positions) to $P$ (prices).

\footnotetext{
${ }^{8}$ See Appendix for the procedure regarding how bootstrap samples are generated for each market.

${ }^{9}$ This approach is a generalization of the methodology developed by Phillips (1995) and Toda and Yamamoto (1995) that does require pretesting for unit roots and cointegration. These authors consider the issue of testing for non-causality in the context of a VAR in levels using the fully modified (FM) estimator. They provide evidence that statistical inference in the context of a VAR in levels can be conducted by means of standard asymptotic theory, i.e., no unit root limit theory is required. Precisely, normal and mixed normal limit theories are applied to the stationary and non-stationary components of the VAR, respectively. Thereby, without prior knowledge of the stationarity properties of series in the system, Wald tests with market-specific bootstrap critical values can be used to test for Granger non-causality.
} 


\section{DATA}

Since 2009, several studies have used Granger causality analysis to examine the relationship between activity on commodity futures markets and prices (see IMF (2008), Büyüksahin and Harris (2009), Brunetti and Büyüksahin (2009), Gilbert (2010a,b), Stoll and Whaley (2010), and Sanders and Irwin (2010, 2011a,b) surveyed by Irwin and Sanders (2011)). This reflects the importance of the issue, but also the availability of new data provided by the US Commodity Futures Trading Commission (CFTC).

Every Friday, the CFTC publishes, the Commitments of Traders (COT) report that provides aggregate positions on the prior Tuesday of traders identified through the CFTC's and the exchanges' reporting systems. The report provides a breakdown of positions held by three different types of traders: "commercial traders" (sometimes known as "speculators"), "noncommercial traders" (considered as "the hedgers") and "nonreportable" (all other traders with position sizes below the reporting level). Since 2007, the CFTC also publishes the Supplemental Commodity Index Traders (CIT) report that contains the positions of index traders for twelve grain, livestock and other soft commodity markets: Chicago Board of Trade (CBOT) corn, CBOT soybeans, CBOT soybean oil, CBOT wheat, Kansas City Board of Trade (KCBT) wheat, New York Board of Trade (NYBOT) cotton, Chicago Mercantile Exchange (CME) live cattle, CME feeder cattle, CME lean hogs, NYBOT coffee, NYBOT sugar, NYBOT cocoa.

A priori, commodity index investments are not speculative. Unlike "traditional" speculators who adopt either long or short positions in order to maximize short-term returns, index traders hold mainly long positions; their investments are passive and essentially motivated by the benefits of portfolio diversification (see Stoll and Whaley (2010)). Nevertheless, the new products that allow individual investors to invest in commodities - i.e. exchange traded funds (ETFs) and structured notes (ETNs) - can still be used for purely speculative motive.

In our empirical study, we consider weekly data on index traders net long positions providing by the CIT reports. Data are publicly available from January 3, 2006 to December 29, 2010. ${ }^{10}$ For all commodities considered, the weekly futures prices are collected from Datastream.

Table 1 reports the weekly average of total open interest for each of the twelve agricultural futures markets before the crisis (Jan. 2006 to Aug. 2008) and during the crisis (Sept. 2008 to Dec. 2010). The two futures contracts the most traded are corn and sugar, which together account for half of the total open interest. At the other extreme, Feeder cattle accounts for only $1 \%$ of the total open interest. Note also that there is a small decrease $(-5 \%)$ of the total open interest between the two periods.

\footnotetext{
${ }^{10}$ Sanders and Irwin (2011b) use the Disaggregated Commitments of Traders (DCOT) database also provided by the CFTC. The DCOT data are available for the same twelve agricultural markets covered by the CIT report and also some energy and metal futures markets. In DCOT report, traders are classified into four groups: swap dealers, managed money, processors and merchants, and other reporting traders. In Sanders and Irwin (2011b) the swap dealers positions are used as a proxy for index traders positions. However, swap dealers in energy markets carry out a substantial amount of non-index swap transactions.
} 
Table 1 - Open interest in agricultural futures markets (weekly average)

\begin{tabular}{lrrrrr}
\hline \hline & \multicolumn{2}{c}{ Before the crisis } & \multicolumn{2}{c}{ During the crisis } \\
(Jan. 06 - Aug. 08) & (Sept. 08 - Dec. 10) & $\begin{array}{r}\text { Changes in } \\
\text { open interest }\end{array}$ \\
\hline Coffee & 185,918 & $(3 \%)$ & 172,028 & $(3 \%)$ & $-7 \%$ \\
Cocoa & 158,786 & $(3 \%)$ & 135,775 & $(3 \%)$ & $-14 \%$ \\
Corn & $1,787,344$ & $(33 \%)$ & $1,532,803$ & $(30 \%)$ & $-14 \%$ \\
Cotton & 314,999 & $(6 \%)$ & 251,656 & $(5 \%)$ & $-20 \%$ \\
Feeder cattle & 34,236 & $(1 \%)$ & 32,041 & $(1 \%)$ & $-6 \%$ \\
Live cattle & 282,403 & $(5 \%)$ & 332,777 & $(6 \%)$ & $18 \%$ \\
Lean hogs & 201,331 & $(4 \%)$ & 201,479 & $(4 \%)$ & $0 \%$ \\
Soybeans & 599,506 & $(11 \%)$ & 592,428 & $(11 \%)$ & $-1 \%$ \\
Soybean oil & 304,530 & $(6 \%)$ & 312,486 & $(6 \%)$ & $3 \%$ \\
Sugar & 920,176 & $(17 \%)$ & $1,004,580$ & $(19 \%)$ & $9 \%$ \\
Wheat CBOT & 504,151 & $(9 \%)$ & 476,082 & $(9 \%)$ & $-6 \%$ \\
Wheat KCBT & 143,491 & $(3 \%)$ & 139,389 & $(3 \%)$ & $-3 \%$ \\
Total & $5,436,871$ & $(100 \%)$ & 518,3525 & $(100 \%)$ & $-5 \%$ \\
\hline \hline
\end{tabular}

Table 2 shows the percentage of total open interest held by long commodity index traders. This percentage is significant for all markets and varies from less than $20 \%$ for cocoa to almost $50 \%$ for lean hogs and wheat CBOT. Overall, there is a small increase of this percentage over the period mid-2008 to 2010, compared to the period 2006 to mid-2008. Actually, most of the increase in commodity index positions occurred from 2004 to 2006 (see Sanders and Irwin (2011a)).

Index traders net positions (number of contracts in million) and futures prices over the period 2006-2010 are represented figure 1. Whatever the commodity, index traders have net long positions throughout the period. Moreover, there is a global upward trend in index traders positions for all the markets, but there is a break in the second semester of 2008 with a sudden drop of their positions. Overall, the markets for which the increase in net positions was less pronounced before the crisis were more resilient than the others.

In terms of the dynamics of futures prices over the period 2006-2010, we can distinguish three groups (see also figure 2): a) on the grain markets (corn, soybeans, soybean oil, CBOT wheat and KCBT wheat), there was a large price increase before the crisis, following by a fall and a rebound; b) livestock markets (feeder cattle, live cattle and lean hogs) were characterized by large price swings, without any particular trend; c) on the other soft commodity markets (cocoa, coffee, cotton, sugar) there was a rather steady price increase, with an acceleration at the end of the period.

Finally, it is interesting to emphasize that correlations between weekly variations in index traders net positions and weekly returns vary a lot (see table 3 ), whether we compare mar- 


\section{Figure 1 - Index traders net long positions and futures prices}
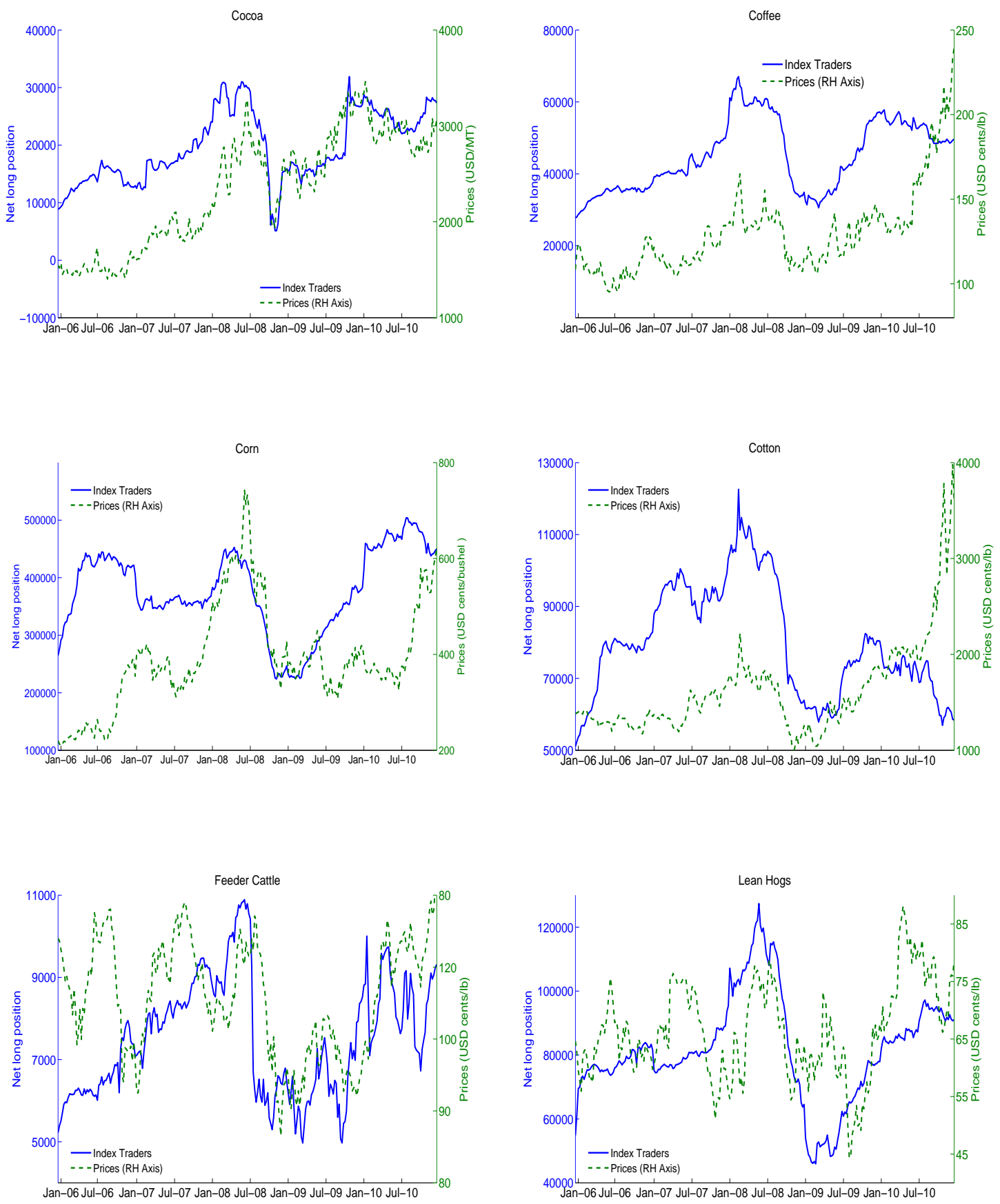

Source: US CFTC (CIT). Authors' calculations. 
Figure 1 - Index traders net long positions and futures prices (continued)
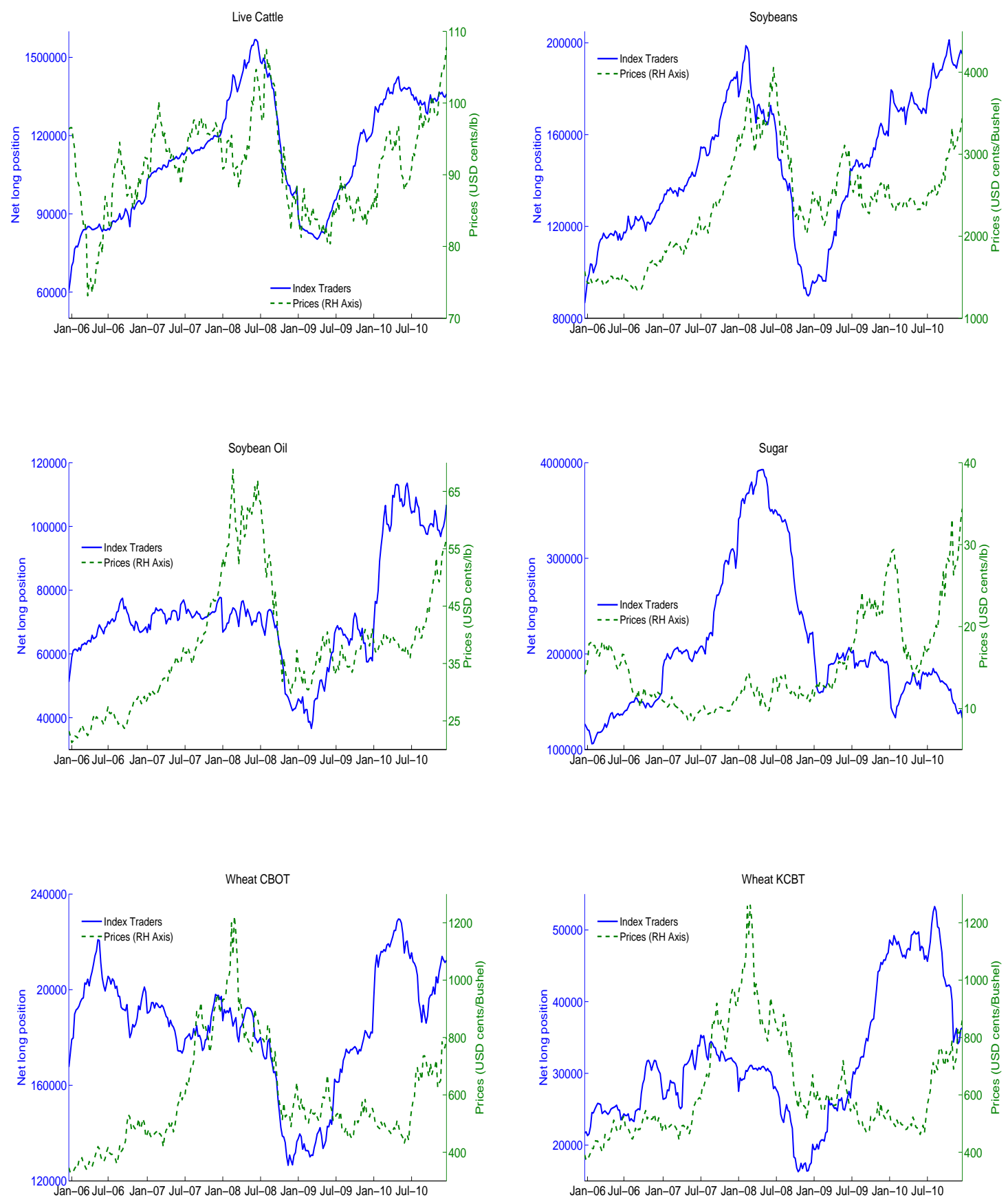

Source: US CFTC (CIT). Authors' calculations. 
Figure 2 - Average returns and variation in index traders net positions

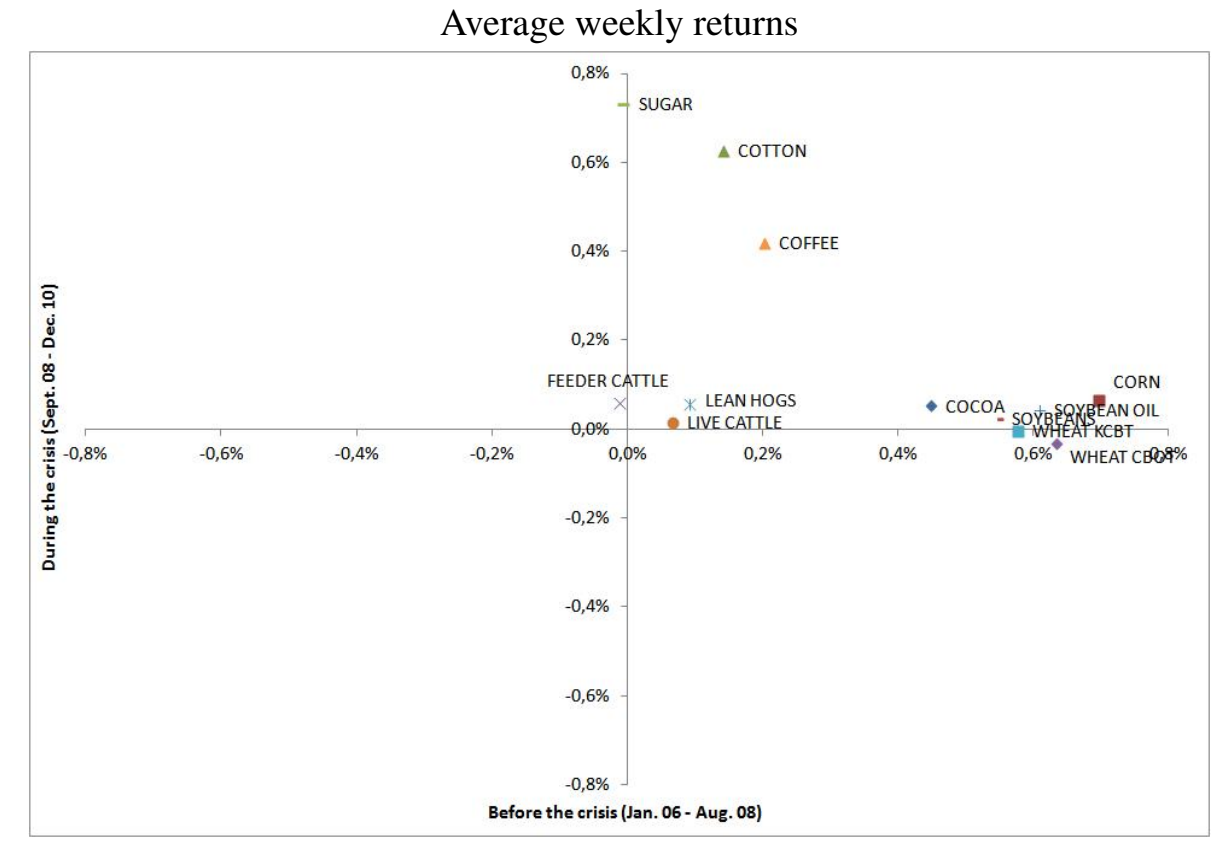

Average weekly variations in index traders net positions

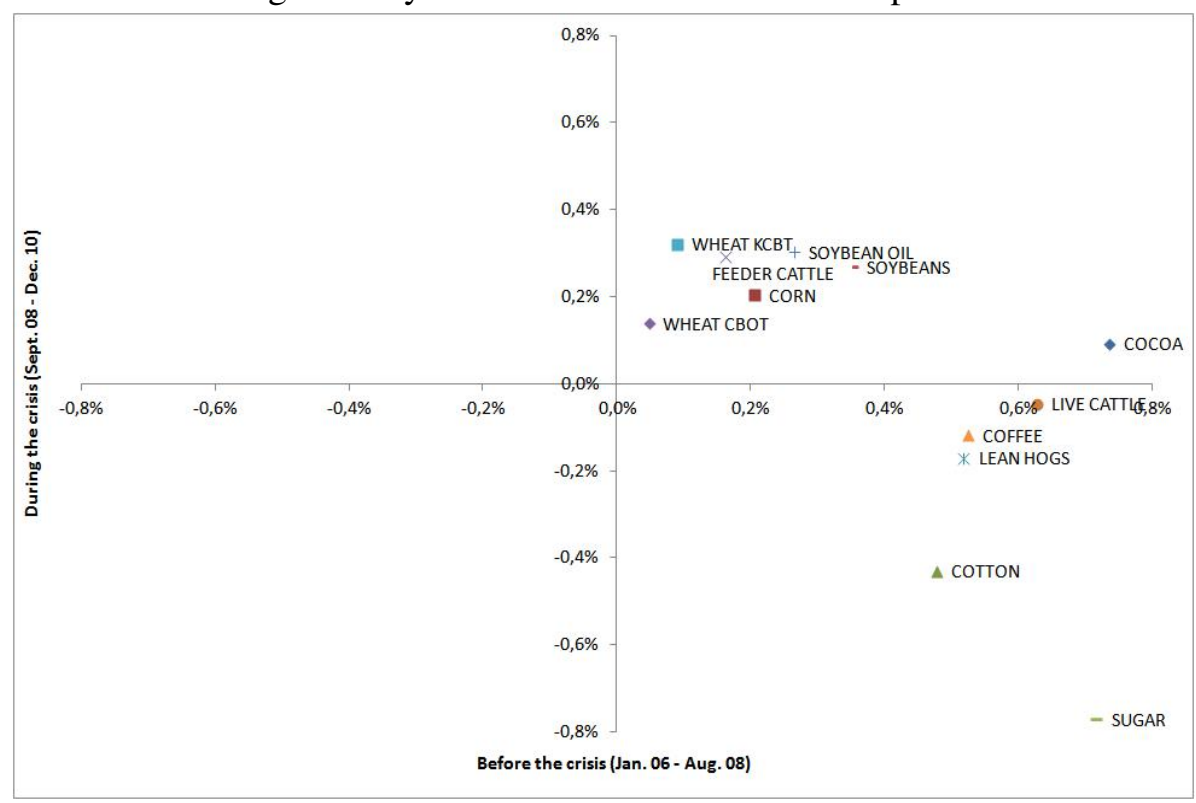

Source: US CFTC (CIT). Authors' calculations. 
Table 2 - Percentage of total open interest held by long commodity index traders

\begin{tabular}{lcc}
\hline \hline & $\begin{array}{c}\text { Before the crisis } \\
\text { (Jan. 06 - Aug. 08) }\end{array}$ & $\begin{array}{c}\text { During the crisis } \\
\text { (Sept. 08 - Dec. 10) }\end{array}$ \\
\hline Coffee & $24 \%$ & $29 \%$ \\
Cocoa & $12 \%$ & $17 \%$ \\
Corn & $23 \%$ & $27 \%$ \\
Cotton & $31 \%$ & $32 \%$ \\
Feeder cattle & $24 \%$ & $26 \%$ \\
Live cattle & $39 \%$ & $36 \%$ \\
Lean hogs & $44 \%$ & $40 \%$ \\
Soybeans & $25 \%$ & $28 \%$ \\
Soybean oil & $24 \%$ & $27 \%$ \\
Sugar & $27 \%$ & $28 \%$ \\
Wheat CBOT & $41 \%$ & $44 \%$ \\
Wheat KCBT & $21 \%$ & $27 \%$ \\
\hline \hline
\end{tabular}

Source: US CFTC (CIT). Authors' calculations.

kets between them or, for each market, the period before the crisis and the period during the crisis.

\section{EMPIRICAL RESULTS}

Since results from the causality test may be sensitive to the lag structure, determining the optimal lag length(s) is crucial for robustness. For a relatively large panel, equation- and variablevarying lag structure would lead to a substantial increase in the computational burden. To overcome this problem, following Kònya (2006), we allow maximal lags to differ across variables, but to be the same across equations. We estimate the system for each possible pair of $l p_{1}$, $l i_{1}, l p_{2}$, and $l i_{2}$ respectively by assuming from 1 to 4 lags and then choose the combinations minimizing the Akaike Information Criterion (AIC) and the Schwarz Bayesian Information Criterion (SBIC). For each bivariate system, AIC and SBIC select the following lags: $l p_{1}=1$, $l i_{1}=1, l p_{2}=4$, and $l i_{2}=1$.

As mentioned above, testing for the cross-sectional dependence in a panel causality study is crucial for selecting the appropriate estimator. Following Kònya (2006), to investigate the existence of cross-sectional dependence, we use the Lagrange multiplier test statistic for cross-sectional dependence of Breusch and Pagan (1980) given by:

$$
C D_{B P}=T \sum_{i=1}^{N-1} \sum_{j=i+1}^{N} \hat{\rho}_{i j}^{2}
$$


Table 3 - Correlation between weekly variations in index traders net positions and weekly returns before and during the crisis

\begin{tabular}{lcc}
\hline \hline & $\begin{array}{c}\text { Before the crisis } \\
\text { (Jan. 06 - Aug. 08) }\end{array}$ & $\begin{array}{c}\text { During the crisis } \\
\text { (Sept. 08 - Dec. 10) }\end{array}$ \\
\hline Coffee & 0.1379 & 0.3545 \\
Cocoa & -0.0051 & 0.3858 \\
Corn & 0.2345 & 0.1768 \\
Cotton & 0.2296 & 0.1485 \\
Feeder cattle & -0.0342 & 0.1027 \\
Live cattle & 0.0103 & 0.3800 \\
Lean hogs & -0.0320 & 0.0373 \\
Soybeans & 0.2979 & 0.2841 \\
Soybean oil & 0.2351 & 0.0801 \\
Sugar & -0.0311 & -0.1012 \\
Wheat CBOT & 0.1152 & 0.2151 \\
Wheat KCBT & 0.1079 & 0.3273 \\
\hline \hline
\end{tabular}

Source: US CFTC (CIT). Authors' calculations.

where $\hat{\rho}_{i j}$ is the estimated correlation coefficient among the residuals obtained from individual OLS estimations. Under the null hypothesis of no cross-sectional dependence with a fixed $\mathrm{N}$ and $T \rightarrow \infty, C D_{B P}$ asymptotically follows a chi-squared distribution with $N(N-1) / 2$ degrees of freedom (Greene (2003), p.350).

Table 4 reports the results of the cross-sectional dependence tests. Since there is an obvious dependence between soybeans and soybean oil markets, and between CBOT wheat and KCBT wheat, for robustness, we report the results using all the twelve markets plus the results excluding soybean, soybean oil, CBOT wheat and KCBT wheat. The results in Table 4 show that the Breusch and Pagan test rejects the null of no cross-sectional dependence across the members of the panel at the $1 \%$ level of significance. The cross-sectional dependence test confirms that strong economic links exist between markets. Even by excluding soybean, soybean oil, CBOT wheat and KCBT wheat, there is a cross-sectional dependence among the other markets. This finding implies that the SUR method is more appropriate than a market-by-market OLS estimation.

Table 5 reports the results of Granger causality tests using all data from January 2006 to December 2010. Since $l p_{1}=1$ and $l i_{1}=1$, for given market $i$, the null hypothesis of causality from index trader position to prices is $H_{0}: \gamma_{1, i, 1}=0$. We can note that the bootstrap critical values are higher than the chi-square critical values usually applied with the Wald test, and that they vary considerably from a market to another and across tables. ${ }^{11}$ In the tables, $\hat{\gamma}_{1, i, 1}$ represents

\footnotetext{
${ }^{11}$ The chi-square critical values for one degree of freedom, i.e. for Wald tests with one restriction, are 6.6349, $3.8415,2.7055$ at the $1 \%, 5 \%$ and $10 \%$ levels, respectively.
} 
Table 4 - Results for cross-sectional dependence tests

\begin{tabular}{lcc}
\hline \hline & All markets included & \\
& $C D_{B P}$ & P-value \\
\hline All periods & $1569.63^{* * *}$ & 0.0000 \\
Before the crisis & $592.75^{* * *}$ & 0.0000 \\
During the crisis & $1049.92^{* * *}$ & 0.0000 \\
\hline
\end{tabular}

Soybeans, Soybean Oil, Wheat-CBOT and Wheat-KCBT excluded

\begin{tabular}{lcc} 
& $C D_{B P}$ & P-value \\
\hline All periods & $456.14 * * *$ & 0.0000 \\
Before the crisis & $233.53 * * *$ & 0.0000 \\
During the crisis & $262.32 * * *$ & 0.0000 \\
\hline \hline
\end{tabular}

$C D_{B P} \overline{\overline{\text { denote the test statistic of Breusch and Pagan Lagrange multiplier statistic for cross- }}}$ sectional dependence. Under the null hypothesis of no cross-sectional dependence, $C D_{B P}$ follows a chi-square distribution with $N(N-1) / 2$ degrees of freedom. $* * *$ indicates rejection of the null hypothesis at the $1 \%$ level. Data: US CFTC (CIT). Authors' calculations.

the estimated coefficient of $I_{i, t-1}$ in the equation testing Granger causality from $I$ to $P$. The results in Table 5 show that, for all the commodities except for live cattle, there is no causality from index traders positions to futures prices. For live cattle, there is a positive causality from index traders positions to prices that is significant at the $10 \%$ level.

As mentioned above, the trend in prices and positions change after financial crisis which started in September 2008. To examine whether the causal link is the same before the financial crisis (January 2006 to September 2008) and during the crisis (September 2008 to December 2010), Tables 6 and 7 report the results using the corresponding data. The results using data before the crisis (Table 6) show that, for all commodities except cocoa, there is no causality from index traders positions to futures prices. For cocoa, there is a positive causality from index traders positions to prices that is significant at the $10 \%$ level. Using data during the crisis (Table 7), the results confirm the findings using all sample, i.e., for live cattle only, there is a positive causality (significant at the $10 \%$ level) from index traders positions to futures prices.

The paper which is the closest to ours is Sanders and Irwin (2011b). The method is similar (SUR estimations, but without specific bootstrap critical values), the source of the data is the same but they consider a proxy for index trader positions (i.e. swap dealer positions) and the period is shorter (2006-2009). Despite these differences, there is no evidence that net positions held by index traders, represented by swap dealers, lead market returns. Sanders and Irwin (2011a) investigate the impact of index traders in U.S. grain futures markets using a standard Granger causality methodology applied to the same dataset but over a previous (and longer) period (2004-2009). Their methodology does not take into account the contemporaneous correlation between the different markets, but they do not find any evidence that commodity index trader positions cause price changes in the Granger sense. Moreover, they show that this result holds for long horizons. Stoll and Whaley (2010) consider the same twelve agricultural markets 
Table 5 - Granger causality tests from index traders net long positions to futures prices (20062010

\begin{tabular}{lrcccc}
\hline \hline Market & $\hat{\gamma}_{1, i, 1}$ & Test Stat. & \multicolumn{3}{c}{ Bootstrap critical values } \\
& & & $1 \%$ & $5 \%$ & $10 \%$ \\
\hline Cocoa & -0.3010 & 0.2750 & 9.1232 & 5.4064 & 3.5876 \\
Coffee & -0.0256 & 0.0079 & 7.9485 & 4.6672 & 3.6596 \\
Corn & 0.0532 & 2.5339 & 9.0241 & 6.0258 & 4.5445 \\
Cotton & -0.2033 & 1.5337 & 7.6398 & 4.9545 & 3.2050 \\
Feeder Cattle & 1.2880 & 2.4085 & 9.0710 & 4.9929 & 3.9695 \\
Live Cattle & 0.1497 & $5.1874 *$ & 8.8093 & 5.5426 & 3.8176 \\
Leans Hogs & 0.2644 & 2.2817 & 8.3820 & 5.0619 & 3.3250 \\
Soybeans & -0.0049 & 0.0036 & 7.8964 & 5.5137 & 3.8986 \\
Soybean Oil & 0.0046 & 0.0019 & 8.9009 & 5.7435 & 3.9008 \\
Sugar & -0.0172 & 0.1135 & 9.6651 & 5.8937 & 4.1262 \\
Wheat-CBOT & -0.0449 & 0.7790 & 9.7015 & 5.5515 & 3.9117 \\
Wheat-KCBT & -0.0979 & 0.6076 & 8.5852 & 5.9380 & 4.5148 \\
\hline \hline
\end{tabular}

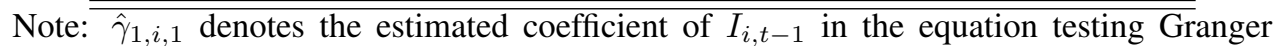
causality from $I$ to $P$. Data: US CFTC (CIT). Authors' calculations. * indicates rejection of the null hypothesis of non-causality at the $10 \%$ level.

Table 6 - Granger causality tests from index traders net long positions to futures prices (before the crisis)

\begin{tabular}{lrlrrr}
\hline \hline Market & $\hat{\gamma}_{1, i, 1}$ & Test Stat. & \multicolumn{3}{c}{ Bootstrap critical values } \\
& & & \multicolumn{1}{c}{$1 \%$} & \multicolumn{1}{c}{$5 \%$} & $10 \%$ \\
\hline Cocoa & 2.9894 & $6.2115^{*}$ & 11.5220 & 7.5086 & 4.9076 \\
Coffee & 1.0701 & 5.9132 & 12.3901 & 7.9813 & 6.1982 \\
Corn & 0.1091 & 2.2117 & 11.4024 & 6.4163 & 4.4631 \\
Cotton & 0.5302 & 5.4859 & 12.9858 & 8.5968 & 6.3023 \\
Feeder Cattle & 1.3397 & 1.5003 & 10.7823 & 7.0689 & 4.9481 \\
Live Cattle & 0.2002 & 4.9596 & 11.6837 & 7.6568 & 6.0138 \\
Leans Hogs & 0.4065 & 3.2620 & 10.9065 & 6.9169 & 5.2641 \\
Soybeans & 0.2987 & 3.8174 & 14.3928 & 7.9719 & 6.3645 \\
Soybean Oil & 0.2059 & 0.1855 & 7.4127 & 5.4279 & 3.6778 \\
Sugar & -0.0114 & 0.0502 & 14.7428 & 9.5010 & 7.6511 \\
Wheat-CBOT & -0.1509 & 0.7432 & 9.7417 & 5.7643 & 4.2040 \\
Wheat-KCBT & 0.0392 & 0.0059 & 12.7362 & 5.9476 & 4.3511 \\
\hline \hline
\end{tabular}

Note: $\hat{\gamma}_{1, i, 1}$ denotes the estimated coefficient of $I_{i, t-1}$ in the equation testing Granger causality from $I$ to $P$. Data: US CFTC (CIT). Authors' calculations. * indicates rejection of the null hypothesis of non-causality at the $10 \%$ level. 
Table 7 - Granger causality tests from index traders net long positions to futures prices (during the crisis)

\begin{tabular}{lrlrrr}
\hline \hline Market & $\hat{\gamma}_{1, i, 1}$ & Test Stat. & \multicolumn{3}{c}{ Bootstrap critical values } \\
& & & $1 \%$ & \multicolumn{1}{c}{$5 \%$} & $10 \%$ \\
\hline Cocoa & -0.6537 & 0.3623 & 10.1268 & 6.5413 & 4.6553 \\
Coffee & 0.0806 & 0.0304 & 12.5479 & 6.7408 & 5.2146 \\
Corn & 0.0210 & 0.3051 & 14.6047 & 7.5346 & 5.8236 \\
Cotton & -0.9738 & 3.5545 & 10.2517 & 5.3102 & 3.6350 \\
Feeder Cattle & 2.6003 & 2.9270 & 8.6778 & 5.9535 & 4.1102 \\
Live Cattle & 0.2617 & $5.6850 *$ & 13.0420 & 6.3917 & 3.5086 \\
Leans Hogs & 0.2734 & 0.8063 & 11.0392 & 7.1268 & 5.3288 \\
Soybeans & -0.0816 & 0.5891 & 13.2380 & 7.4797 & 5.4482 \\
Soybean Oil & 0.0811 & 0.3447 & 13.6362 & 7.7517 & 5.2996 \\
Sugar & 0.0118 & 0.0052 & 12.8975 & 6.2779 & 4.6721 \\
Wheat-CBOT & -0.0565 & 0.7448 & 9.8737 & 5.3293 & 3.7263 \\
Wheat-KCBT & -0.1430 & 0.7145 & 10.2329 & 7.3007 & 4.7649 \\
\hline
\end{tabular}

Note: $\hat{\gamma}_{1, i, 1}$ denotes the estimated coefficient of $I_{i, t-1}$ in the equation testing Granger causality from $I$ to $P$. Data: US CFTC (CIT). Authors' calculations. * indicates rejection of the null hypothesis of non-causality at the $10 \%$ level.

over the period 2006-2009, using the standard Granger causality methodology, and do not evidence of causality, except for cotton. Brunetti and Büyüksahin (2009) use not-publicly available data provided by the CFTC Large Trader Reporting System which allows them to identify positions of each trader category in each futures contract for every contract maturity on each day. They test, in a simple multivariate framework, Granger causality between the daily rate of returns of futures contract on corn (and other non-agricultural markets) and the daily positions of the five most important categories of market participants to examine whether speculators cause price movements and volatility in futures markets. They show that speculative trading activity does not have a significant effect. Overall, we can conclude that there is almost no statistical evidence of causal relationships from index positions in the agricultural futures markets and prices, whatever the time interval or the econometric method.

However, absence of causality does not mean that the composition of the trading activity has no impact at all. For instance, Büyüksahin and Robe (2011) find significant changes in the composition of the trading activity in U.S. energy futures markets during the 2000s, and show that these changes have impacted asset pricing (specially, the dynamic conditional correlations between the rates of return on investable energy and stock market indices). 


\section{Conclusion}

Since the mid-2000s, prices of agricultural commodities rose substantially. The increasing importance of financial investment in commodity trading has been viewed as a source of this prices surge. This paper examines the causality between index investors positions and commodity prices on twelve grain, livestock, and other soft commodity markets. We use the panel Granger causality testing approach that uses SUR systems and Wald tests with market specific bootstrap critical values. This approach allows to test for Granger-causality on each individual market separately by taking into account the possible contemporaneous correlation across markets.

Our results show that, in agricultural futures markets, there is no evidence of a causality relationship from index funds to futures prices. This result holds for the period 2006-2010, but also for the sub-periods 2006-2008 and 2008-2010. These findings imply that index-based trading has not been an important driver in the substantial increase in commodities prices. Changes in commodity prices may instead reflect fundamental supply and demand factors.

\section{REFERENCES}

Arouri, M., Rault, Ch., 2010. Causal relationships between oil and stock prices: Some new evidence from gulf oil-exporting countries, International Economics, 122.

Baumol, W. J., 1957. Speculation, profitability, and stability, Review of Economics and Statistics, 39, 263-71.

Breusch, T., Pagan, A., 1980. The LM test and its applications to model specification in econometrics, Review of Economic Studies, 47, 239-254.

Brorsen, B.W., Oellermann, C.M., and Farris, P.L., 1989. The live cattle futures market and daily cash price movements, Journal of Futures Markets, 9(4), 273-282.

Brunetti, C., Büyüksahin, B., 2009. Is speculation destabilizing?, Working Paper.

Büyüksahin, B., Harris, J.H. 2009. The role of speculators in the crude oil futures markets, Working Paper, U.S. Commodity Futures Trading Commission, 2009.

Büyüksahin, B., Robe, M., 2011. Does 'Paper Oil’ Matter? Energy Market Financialization and Equity-Energy Linkages, Working Paper.

Capelle-Blancard, G., 2010. Are derivatives dangerous? A literature survey, International Economics, 123

Chari, V. V., Jagannathan, R., Jones, L., 1990. Price stability and futures trading in commodities, The Quarterly Journal of Economics, 105(2), 527-34.

Danthine, J.-P., 1978. Information, futures prices, and stabilizing speculation, Journal of Economic Theory, 17(1), 79-98. 
DeLong, J.B., Shleifer, A., Summers, L.H., and Waldmann, R.J., 1990. Noise trader risk in financial markets, Journal of Political Economy, 98(4), 703-738.

Domanski, D., Heath, A., (2007), Financial investors and commodity markets. BIS Quarterly Review March, 53-67.

Emery, H.C., 1898. Speculation on the stock and produce exchanges of the United States, AMS Press, New York.

Fleming, J., Ostdiek, B., 1999. The impact of energy derivatives on the crude oil market Energy Economics, 21(2), 135-167

Frankel, J., Rose, A.K., 2010. Determinants of agricultural and mineral commodity prices, Working Paper Series wp10-038, Harvard University, John F. Kennedy School of Government.

Gilbert, C. L., 2010a. Speculative influence on commodities futures prices 2006-2008, UNCTAD Discussion Paper No. 197

,2010b. Commodity speculation and commodity investment, Commodity Market Review, 25-46.

Gorton, G.B., Rouwenhorst, K.G., 2006. Facts and fantasies about commodity futures, Financial Analysts Journal, 62(2), 47-68.

Greene, W.H., 2003. Econometric Analysis, 2nd ed. Prentice-Hall.

Guesnerie, R., Rochet, J.-C., 1993. (De)stabilizing speculation on futures markets : An alternative view point, European Economic Review, 37(5), 1043-1063.

Hart, O.D., Kreps, D.M., 1986. Price destabilizing speculation, Journal of Political Economy, 94(5), 927-52,

Hernandez, M., Torero, M., 2010. Examining the dynamic relationship between spot and futures prices of agricultural commodities, IFPRI discussion papers 988, International Food Policy Research Institute (IFPRI).

Hooker, B.A., 1901. The suspension of the Berlin produce exchange and its effect upon corn prices, Journal of the Royal Statistical Society, 64(4), 574-613.

Hurlin, C., 2008. Testing for Granger non causality in heterogeneous panels. Mimeo, Department of Economics: University of Orleans.

Kawai, M., 1983. Spot and futures prices of nonsotrable commodities under rational expectations, The Quarterly Journal of Economics, 98(2), 235-254.

IMF, (2008), Global financial stability report. Washington, DC, International Monetary Fund.

Irwin, S.H. and Sanders, D.R., 2011. Index funds, financialization, and commodity futures markets, Applied Economic Perspectives and Policy, 33, 1-31.

Kònya, L. 2006. Exports and growth: Granger causality analysis on OECD Countries with a panel data approach, Economic Modelling, 23, 978-992.

Mayhew, S., 2002. Competition, market structure, and bid-ask spreads in stock option markets, 
Journal of Finance, 57(2), 931-958.

Netz, J.S., 1995. The effect of futures markets and corners on storage and spot price variability, American Journal of Agricultural Economics, 77(2), 182-193.

Peck, A.E., 1976. Futures markets, supply response and price stability, Quarterly Journal of Economics, 90, 407-423.

Pesaran, M.H., Shin, Y., Smith, R.J., 1999. Pooled mean group estimation of dynamic heterogeneous panels, Journal of the American Statistical Association, 94( 446), 621-634.

Phillips, P.C.B., 1995. Fully modified least squares and vector autoregression, Econometrica, 63, 1023-1078.

Stein, J.C., 1987. Informational externalities and welfare-reducing speculation, Journal of Political Economy, 95(6), 1123-1145.

Sanders, D.R., and Irwin, S.H., 2010. A speculative bubble in commodity futures prices? Crosssectional evidence, Agricultural Economics, 41, 25-32.

, 2011a. New evidence on the impact of index funds in U.S. grain futures markets, Canadian Journal of Agricultural Economics, 59(4), 519-532.

2011b. The impact of index funds in commodity futures markets: A systems approach" The Journal of Alternative Investments, 14(1), 40-49.

Singleton, K.J., 2011. Investor flows and the 2008 boom/bust in oil prices, Working paper, Stanford Graduate School of Business.

Stoll, H.R., Whaley, R.E., 2010. Commodity index investing and commodity futures prices, Journal of Applied Finance 1.

Tang, K., Xiong, W., 2011. Index investing and the financialization of commodities, Working paper, Princeton University.

Taylor, G., Leuthold, R., 1974. The influence of futures trading on cash cattle price variations, Food Research Institute Studies, 13(1), 29-35.

Toda, H.Y., Yamamoto, T., 1995. Statistical inference in vector autoregressions with possibly integrated processes, Journal of Econometrics, 66(1-2), 225-250.

Tomek, W.G., 1971. A note on historical wheat prices and futures trading, Food Research Institute Studies 10(1), 109-113.

Turnovsky, S.J., 1983. The determination of spot and futures prices with storable commodities, Econometrica, 51, 1363-1388.

Weaver, R.D., Banerjee, A., 1990. Does futures trading destabilize cash prices? Evidence from U.S. live beef cattle, Journal of Futures Markets 2(4), 367-389.

Zellner, A., 1962. An efficient method of estimating seemingly unrelated regressions and tests for aggregation bias, Journal of the American Statistical Association 57, 348-368. 


\section{APPENDIX: THE BOOTSTRAP PROCEDURE}

The procedure to generate bootstrap samples and market specific critical values (in the test of no causality from $X$ to $Y$ ) consists of the following five steps (Konya, 2006)

1st step: Implement an estimation of (2) under the null hypothesis of no-causality from $\mathrm{X}$ to $\mathrm{Y}$ by (i.e. imposing $\gamma_{1, i, s}=0$ the for all $i$ and $s$ ) and get the corresponding residuals:

$$
e_{H_{0}, i, t}=y_{i, t}-\hat{\alpha}_{i, 1}+\sum_{s=1}^{l y_{1}} \hat{\beta}_{1, i, s} y_{i, t-s}
$$

$>$ From these residuals, build the $N \times T\left[e_{H_{0}, i, t}\right]$ matrix.

2nd step: In order to preserve the contemporaneous dependence between error terms in (2), randomly select a full column from $\left[e_{H_{0}, i, t}\right]$ matrix at a time (i.e do not draw the residuals for each market one by one); and denote the selected bootstrap residuals as $\left[e_{H_{0}, i, t}^{*}\right]$ where $t=1, \ldots, T^{*}$ and $T^{*}$ can be greater than $\mathrm{T}$.

3rd step: Build the bootstrap sample of $\mathrm{Y}$ under the hypothesis of no-causality from $\mathrm{X}$ to $\mathrm{Y}$, i.e. using the following formula:

$$
y_{i, t}^{*}=\hat{\alpha}_{i, 1}+\sum_{s=1}^{l y_{1}} \hat{\beta}_{1, i, s} y_{i, t-s}^{*}+e_{H_{0}, i, t}^{*}
$$

4th step: Replace $y_{i, t}$ by $y_{i, t}^{*}$, estimate (2) without any parameter restrictions and then implement the Wald test for each market to test for the no-causality null hypothesis.

5th step: Develop the empirical distributions of the Wald test statistics by repeating $(10,000$ replications) the steps 2-4 many times and build the bootstrap critical values. 


\section{LIST OF WORKING PAPERS RELEASED BY CEPII}

An Exhaustive list is available on the website: Ilwww.cepii.fr..

No

2011-27 The Impossible Trinity Revised: An Application to China

2011-26 Isolating the Network Effect of Immigrants on Trade

2011-25 Notes on CEPII's Distances Measures: the GeoDist Database

2011-24 Estimations of Tariff Equivalents for the Services Sectors

2011-26 Isolating the Network Effect of Immigrants on Trade

2011-25 Notes on CEPII's distances measures: The Geodist database

2011-24 Estimations of Tariff Equivalents for the Services Sectors

2011-23 Economic Impact of Potential Outcome of the DDA

2011-22 More Bankers, more Growth? Evidence from OECD Countries

2011-21 EMU, EU, Market Integration and Consumption Smoothing

2011-20 Real Time Data and Fiscal Policy Analysis

2011-19 On the inclusion of the Chinese renminbi in the SDR basket
Authors

B. Carton

M. Aleksynska \& G. Peri

T. Mayer \& S. Zignago

L. Fontagné, A. Guillin \& C. Mitaritonna

M. Aleksynska \& G. Peri

T. Mayer \& S. Zignago

L. Fontagné, A. Guillin \& C. Mitaritonna

Y. Decreux \& L. Fontagné

G. Capelle-Blancard \& C. Labonne

A. Christev \& J. Mélitz J. Cimadomo

A. Bénassy-Quéré \& D. Capelle 
No

Tittle

2011-18 Unilateral trade reform, Market Access and Foreign Competition: the Patterns of Multi-Product Exporters

2011-17 The "Forward Premium Puzzle" and the Sovereign Default Risk

2011-16 Occupation-Eduction Mismatch of Immigrant Workers in Europe: Context and Policies

2011-15 Does Importing More Inputs Raise Exports? Firm Level Evidence from France

2011-14 Joint Estimates of Automatic and Discretionary Fiscal Policy: the OECD 1981-2003

2011-13 Immigration, vieillissement démographique et financement de la protection sociale : une évaluation par l'équilibre général calculable appliqué à la France

2011-12 The Performance of Socially Responsible Funds: Does the Screening Process Matter?

2011-11 Market Size, Competition, and the Product Mix of Exporters

2011-10 The Trade Unit Values Database

2011-09 Carbon Price Drivers: Phase I versus Phase II Equilibrium

2011-08 Rebalancing Growth in China: An International Perspective

2011-07 Economic Integration in the EuroMed: Current Status and Review of Studies

2011-06 The Decision to Import Capital Goods in India: Firms' Financial Factors Matter

2011-05 FDI from the South: the Role of Institutional Distance and Natural Resources

\section{Authors}

M. Bas \& P. Bombarda

V. Coudert \& V. Mignon

M. Aleksynska \& A. Tritah

M. Bas

\& V. Strauss-Kahn

J. Darby \& J. Mélitz

X. Chojnicki \& L. Ragot

G. Capelle-Blancard \& S. Monjon

T. Mayer, M. Melitz \& G. Ottaviano

A. Berthou \& C. Emlinger

A. Creti, P.-A. Jouvet \& V. Mignon

A. Bénassy-Quéré, B. Carton \& L. Gauvin

J. Jarreau

A. Berthou \& M. Bas

M. Aleksynska \& O. Havrylchyk 
No

Tittle

2011-04b What International Monetary System for a fastchanging World Economy?

2011-04a Quel système monétaire international pour une économie mondiale en mutation rapide?

2011-03 China's Foreign Trade in the Perspective of a more Balanced Economic Growth

2011-02 The Interactions between the Credit Default Swap and the Bond Markets in Financial Turmoil

2011-01 Comparative Advantage and Within-Industry Firms Performance

2010-33 Export Performance and Credit Constraints in China

2010-32 Export Performance of China's domestic Firms: The Role of Foreign Export Spillovers

2010-31 Wholesalers in International Trade

2010-30 TVA et taux de marge : une analyse empirique sur données d'entreprises

2010-29 Economic and Cultural Assimilation and Integration of Immigrants in Europe

2010-28 Les firmes françaises dans le commerce de service

2010-27 The world Economy in 2050: a Tentative Picture

2010-26 Determinants and Pervasiveness of the Evasion of Customs Duties

2010-25 On the Link between Credit Procyclicality and Bank Competition

\section{Authors}

A. Bénassy-Quéré \& J. Pisani-Ferry

A. Bénassy-Quéré \& J. Pisani-Ferry

G. Gaulier, F. Lemoine \& D. Ünal

V. Coudert \& M. Gex

M. Crozet \& F. Trionfetti

J. Jarreau \& S. Poncet

F. Mayneris \& S. Poncet

M. Crozet, G. Lalanne \& S. Poncet

P. Andra, M. Carré \& A. Bénassy-Quéré

M. Aleksynska \& Y. Algan

G. Gaulier, E. Milet \& D. Mirza

J. Fouré, A. Bénassy-Quéré \& L. Fontagné

S. Jean

\& C. Mitaritonna

V. Bouvatier,

A. Lopez-Villavicencio

\& V. Mignon 
No

Tittle

Authors

2010-24 Are Derivatives Dangerous? A Literature Survey

G. Capelle-Blancard

2010-23 BACI: International Trade Database at the ProductLevel - The 1994-2007 Version

G. Gaulier \& Soledad Zignago

2010-22 Indirect Exporters

F. McCann

2010-21 Réformes des retraites en France: évaluation de la mise en place d'un système par comptes notionnels

X. Chojnicki \& R. Magnani

2010-20 The Art of Exceptions: Sensitive Products in the Doha Negotiations

C. Gouel, C. Mitaritonna \& M.P. Ramos

2010-19 Measuring Intangible Capital Investment: an Application to the "French Data"

V. Delbecque \& L. Nayman

2010-18 Clustering the Winners: The French Policy of Competitiveness Clusters

L. Fontagné, P. Koenig, F. Mayneris \&S. Poncet

2010-17 The Credit Default Swap Market and the Settlement of Large Defauts

2010-16 The Impact of the 2007-10 Crisis on the Geography of Finance

V. Coudert \& M. Gex

2010-15 Socially Responsible Investing : It Takes more than Words

G. Capelle-Blancard \& Y. Tadjeddine

G. Capelle-Blancard \& S. Monjon

2010-14 A Case for Intermediate Exchange-Rate Regimes

V. Salins

\& A. Bénassy-Quéré

2010-13 Gold and Financial Assets: Are they any Safe Havens in Bear Markets?

V. Coudert \& H. Raymond

2010-12 European Export Performance

A. Cheptea, L. Fontagné \& S. Zignago

2010-11 The Effects of the Subprime Crisis on the Latin American Financial Markets: An Empirical Assessment

G. Dufrénot, V. Mignon \& A. Péguin-Feissolle

2010-10 Foreign Bank Presence and its Effect on Firm Entry and Exit in Transition Economies

O. Havrylchyk 
No

Tittle

2010-09 The Disorted Effect of Financial Development on International Trade Flows

2010-08 Exchange Rate Flexibility across Financial Crises

2010-07 Crises and the Collapse of World Trade: The Shift to Lower Quality

2010-06 The heterogeneous effect of international outsourcing on firm productivity

2010-05 Fiscal Expectations on the Stability and Growth Pact: Evidence from Survey Data

2010-04 Terrorism Networks and Trade: Does the Neighbor Hurt

2010-03 Wage Bargaining and the Boundaries of the Multinational Firm

2010-02 Estimation of Consistent Multi-Country FEERs

2010-01 The Elusive Impact of Investing Abroad for Japanese Parent Firms: Can Disaggregation According to FDI Motives Help

\section{Authors}

A. Berthou

V. Coudert, C. Couharde \& V. Mignon

A. Berthou \& C. Emlinger

Fergal McCann

M. Poplawski-Ribeiro \& J.C. Rüle

J. de Sousa, D. Mirza \& T. Verdier

M. Bas \& J. Carluccio

B. Carton \& K. Hervé

L. Hering, T. Inui \& S. Poncet 
Organisme public d'étude et de recherche en économie internationale, le CEPII est placé auprès du Centre d'Analyse Stratégique. Son programme de travail est fixé par un conseil composé de responsables de l'administration et de personnalités issues des entreprises, des organisations syndicales et de l’Université.

Les documents de travail du CEPII mettent à disposition du public professionnel des travaux effectués au CEPII, dans leur phase d'élaboration et de discussion avant publication définitive. Les documents de travail sont publiés sous la responsabilité de la direction du CEPII et n'engagent ni le conseil du Centre, ni le Centre d'Analyse Stratégique. Les opinions qui y sont exprimées sont celles des auteurs.

Les documents de travail du CEPII sont disponibles sur le site : http//www.cepii.fr. 